\title{
Validation of quantitative RP-HPLC-DAD method and extraction optimization of 4-methoxycinnamyl p-coumarate and trans-4- methoxycinnamaldehyde in Etlingera pavieana rhizomes
}

\author{
Klaokwan Srisook ${ }^{1,2 \dagger}$ (D), Chartchai Malapong ${ }^{3 \dagger}$, Petchrat Sawai ${ }^{1}$, Ekaruth Srisook ${ }^{1,4^{*}}$ (D) \\ ${ }^{1}$ Department of Biochemistry and Research Unit of Natural Bioactive Compounds for Healthcare Products Development, Faculty of Science, Burapha \\ University, Chonburi, Thailand. \\ ${ }^{2}$ Center of Excellence for Innovation in Chemistry, Faculty of Science, Burapha University, Chonburi, Thailand. \\ ${ }^{3}$ Science Innovation Facility, Faculty of Science, Burapha University, Chonburi, Thailand. \\ ${ }^{4}$ Department of Chemistry and Research Unit of Natural Bioactive Compounds for Healthcare Products Development, Faculty of Science, Burapha \\ University, Chonburi, Thailand.
}

\begin{tabular}{|c|c|}
\hline ARTICLE INFO & ABSTRACT \\
\hline $\begin{array}{l}\text { Received on: 09/06/2021 } \\
\text { Accepted on: } 28 / 08 / 2021 \\
\text { Available online: } 03 / 10 / 2021\end{array}$ & $\begin{array}{l}\text { Etlingera pavieana is known as a spice and medicinal plant. According to previous reports, E. pavieana extracts } \\
\text { exhibit various biological activities. However, the content of the primary phenylpropanoids of the E. pavieana } \\
\text { rhizomal extract, 4-methoxycinnamyl } p \text {-coumarate (MCC) and trans-4-methoxycinnamaldehyde (MCD), has not been } \\
\text { determined. This study was designed to validate a reversed-phase high-performance liquid chromatography method }\end{array}$ \\
\hline $\begin{array}{l}\text { Key words: } \\
\text { Etlingera pavieana, } \\
\text { extraction solvent, HPLC, } \\
\text { 4-methoxycinnamyl } \\
\text { p-coumarate, trans-4- } \\
\text { methoxycinnamaldehyde, } \\
\text { validation. }\end{array}$ & $\begin{array}{l}\text { that quantified MCC and MCD from E. pavieana extracts. The method was validated based on the international council } \\
\text { for harmonization (ICH) guidelines. The method displayed acceptable validation parameters, such as an excellent } \\
\text { correlation coefficient higher than } 0.999 \text {. The linearities of the response range of MCD and MCC were } 1.00-20.00 \\
\text { and } 2.5-60.00 \mu \mathrm{g} / \mathrm{ml} \text {, respectively. The limit of detection and limit of quantitation were found to be } 4.16 \text { and } 12.48 \\
\mathrm{ng} / \mathrm{ml} \text {, respectively, for MCD and } 10.42 \text { and } 31.26 \mathrm{ng} / \mathrm{ml} \text {, respectively, for MCC. The percentage relative standard } \\
\text { deviation (RSD) of repeatability and intermediate precision were } 1.03 \%-5.80 \% \text { and } 3.14 \%-6.84 \% \text {, respectively. The } \\
\text { ethyl acetate extracts prepared by the maceration and reflux method yielded the largest amount of MCD and MCC. } \\
\text { This study confirmed that the high-performance liquid chromatography method for the simultaneous analysis of MCD } \\
\text { and MCC was accurate, sensitive, and reproducible. This method can be used to quantitate the content of MCD and } \\
\text { MCC in E. pavieana extracts. }\end{array}$ \\
\hline
\end{tabular}

\section{INTRODUCTION}

Etlingera pavieana (Pierre ex Gagnep) R.M.Sm., belonging to the family Zingiberaceae, is used as a food and medicinal herb in Southeast Asia (Poulsen \& Phonsena, 2017). Etlingera pavieana rhizome extracts exhibit anti-inflammatory (Srisook et al., 2017, 2020), antioxidant (Srisook et al., 2018),

\section{${ }^{*}$ Corresponding Author}

Ekaruth Srisook, Department of Biochemistry and Research Unit of Natural Bioactive Compounds for Healthcare Products Development, Faculty of Science, Burapha University, Chonburi, Thailand.

E-mail: ekaruth@go.buu.ac.th

†These authors contributed equally to this work. antimicrobial (Naksang et al., 2020; Tachai \& Nuntawong, 2016), and cytotoxic effects (Iawsipo et al., 2018; Tachai \& Nuntawong, 2016). Thus, E. pavieana is believed to have health benefits.

Various phenylpropanoids are isolated from $E$. pavieana rhizomes (EPE) (Srisook et al., 2017). Among them, 4-methoxycinnamyl $p$-coumarate (MCC) and trans4-methoxycinnamaldehyde (MCD) are the primary phytoconstituents. They exhibit potent anti-inflammatory activity by suppressing inflammatory mediators and cytokines as well as endothelial adhesion molecules (Mankhong et al., 2019; Srisook et al., 2019, 2020). Thus, E. pavieana can be a new source of MCC and MCD for functional foods and dietary supplements for the prevention of inflammation-related diseases. However, the quantity of these active compounds in E. pavieana rhizome 
extracts has not been described. A sensitive and reliable method for determining MCC and MCD is necessary to control the quality of the herbal products containing E. pavieana extract.

The present study aimed to validate a high-performance liquid chromatography (HPLC) method to quantify MCC and MCD extracted from EPE according to the International Council for Harmonization $(\mathrm{ICH})$ guidelines. In addition, the validated method was applied to determine the compound contents in $E$. pavieana extracts prepared with different solvents and methods to identify the optimal extraction procedure of the plant rhizomes.

\section{EXPERIMENTALS AND METHODS}

\section{Materials}

HPLC-grade methanol (Honeywell Burdick \& Jackson, Seoul, Korea) was purchased and deionized water was prepared with a water purification system (MicroPure UV Thermo Scientific, Budapest, Hungary). MCC and MCD were extracted as described by Srisook et al. (2017). The purity of MCD (Supplementary Figure S1) and MCC (Mankhong et al., 2019) determined by HPLC was more than $97 \%$.

\section{Plant extraction}

The rhizomes of E. pavieana (Pierre ex Gagnep.) R.M.Sm. were dehydrated in a hot air dryer at $50^{\circ} \mathrm{C}$ and finely ground. The plant powder was extracted with different organic solvents, ethanol, $70 \%$ ethanol, $40 \%$ ethanol, and ethyl acetate, using the maceration or reflux method. For maceration extraction, $20 \mathrm{~g}$ of plant powder was macerated in $200 \mathrm{ml}$ of extraction solvent at room temperature with continuous shaking for 6 hours and further placed for another 18 hours. The process was performed in triplicate. For reflux extraction, $20 \mathrm{~g}$ of the plant powder was soaked in $200 \mathrm{ml}$ of solvent, refluxed for 1 hours. The extract solvent was filtered and evaporated using a rotatory evaporator.

\section{Stock standard solution and working standard solution}

Five milligrams of MCC and MCD each was transferred to a microtube and dissolved in methanol to prepare a $5 \mathrm{mg} / \mathrm{ml}$ standard solution. The standard solutions were stored at $-20^{\circ} \mathrm{C}$. The working solution was freshly prepared by diluting the standard solution with methanol and filtered through a $0.45-\mu \mathrm{m}$ membrane filter.

\section{Chromatographic conditions}

MCC and MCD were separated using the HPLC technique as described by Srisook et al. (2020). The HPLC system consisted of a quaternary pump system, an autosampler, and a diode array detector on the HPLC Agilent 1260 Infinity II platform (Agilent Technology, Wood Dale, IL). The column Phenomenex Luna C18 $(4.6 \times 250 \mathrm{~mm}, 5-\mu \mathrm{m})$ was used and maintained at $35^{\circ} \mathrm{C}$. The mobile phase of methanol: water $(70: 30 \mathrm{v} / \mathrm{v})$ was applied during isocratic elution. The flow rate was set to $1.0 \mathrm{ml} /$ minute. The injection volume was $10 \mu \mathrm{l}$. The detector wavelength was set at $320 \mathrm{~nm}$. The total run time was 30 minutes.

\section{Method performance characteristic}

The analytical characteristics of the proposed methods for MCD and MCC were investigated for optimum conditions. Each method was validated for linearity, the limit of detection (LOD), the limit of quantification (LOQ), precision, and accuracy following the ICH of Technical Requirements for Pharmaceuticals for Human Use (ICH, 2005).

\section{Linearity}

The linearity was determined using the standard working solutions of MCD at $0.05-200 \mu \mathrm{g} / \mathrm{ml}$ and MCC at $0.125-200 \mu \mathrm{g} /$ $\mathrm{ml}$. The concentration at each standard solution was analyzed in triplicate. The linearity was obtained from the plot between the peak area (y-axis) and the concentration of the MCD and MCC standard solutions.

\section{Precision}

The method's precision was determined at the low, middle, and high concentrations in the calibration curve. The repeatability was determined by analyzing and calculating the relative standard deviation (RSD) 10 times within 1 day. The intermediate precision was determined by analyzing and calculating the RSD for nine consecutive days. The precision was expressed by the percent relative standard deviation (\%RSD) as follows:

$$
\% \operatorname{RSD}=\frac{\mathrm{SD}}{\overline{\mathrm{x}}} \times 100
$$

\section{Accuracy}

The accuracy of the proposed method was expressed in terms of recovery. Recovery was studied by spiking MCD and MCC at low, middle, or high concentrations into $5 \mathrm{mg}$ of crude extract and performing the analysis in triplicate $(n=3)$. The percent recovery was calculated as follows:

$$
\text { recovery }=\frac{\mathrm{C}_{\text {Sample }+ \text { Standard }}-\mathrm{C}_{\text {Sample }}}{\mathrm{C}_{\text {Standard }}} \times 100
$$

\section{$L O D$ and $L O Q$}

A standard solution was diluted to the lowest concentration by methanol. The signal-to-noise $(\mathrm{S} / \mathrm{N})$ ratios of 3 and 10 were used to determine the LOD and LOQ, respectively.

\section{Preparation of crude extract sample}

Five milligrams of dried crude extract were dissolved in methanol. After filtrating with a $0.45-\mu \mathrm{m}$ membrane filter, the extract solution was injected into the HPLC system.

\section{Statistical analysis}

All data were expressed as the means \pm standard deviations of triplicate measurements. A factorial design was applied to the study with two parameters, solvent types and extraction methods. The results were analyzed using the Minitab software version 17.1. The experimental groups were compared using one-way analysis of variance followed by Tukey's multiple comparison tests; the differences with a statistical significance of $p<0.05$ were considered to be significant.

\section{RESULTS AND DISCUSSION}

\section{Method validation}

HPLC was used to analyze MCD and MCC in $E$. pavieana rhizome extracts. MCD and MCC were separated in 
reversed-phase high-performance liquid chromatography and detected at the maximum absorbance of $320 \mathrm{~nm}$. According to the MCD and MCC chromatograms under the optimal condition (Fig. $1 \mathrm{~A})$, symmetric and well-resolved peaks for MCD and MCC were yielded under this condition. The retention times $\left(R_{\mathrm{t}}\right)$ of MCD and MCC were 4.5 and 13.6 minutes, respectively. On the other hand, the chromatogram of the ethanol-extract EPE was shown (Fig. 1B). The specificity of the validated method was established by comparing the $R_{\mathrm{t}}$ and the absorption spectra of the peaks of the $E$. pavieana-extracted MCD and MCC.

The analytical characteristics of the proposed method were determined following the ICH guidelines. The regression equation was summarized in Table 1. The calibration curve was obtained by plotting the integrated peak area and concentration of MCD and MCC (Supplement data Figure S-2). The calibration curves of MCD and MCC were found to be linear in the ranges of 1.0-20.00 and $2.0-60.00 \mu \mathrm{g} / \mathrm{ml}$, respectively (Table 1). The correlation coefficient $\left(R^{2}\right)$ was more than 0.999 for MCD and MCC.

The LOD is defined as the lowest concentration of detection, and the LOQ is defined as the lowest quantifiable amount of analyte in the sample. Both values were obtained using the $\mathrm{S} / \mathrm{N}$ ratio method. The standard solution was further diluted to a known low concentration and injected into HPLC for determination of the $\mathrm{S} / \mathrm{N}$ ratio. The $\mathrm{S} / \mathrm{N}$ ratios of 3 and 10 were used to estimated LOD and LOQ, respectively. The LOD and LOQ were determined to be 4.16 and $12.48 \mathrm{ng} / \mathrm{ml}$, respectively, for MCD and 10.42 and 31.26 $\mathrm{ng} / \mathrm{ml}$, respectively, for MCC (Table 1). These data confirmed the sensitivity of the method.
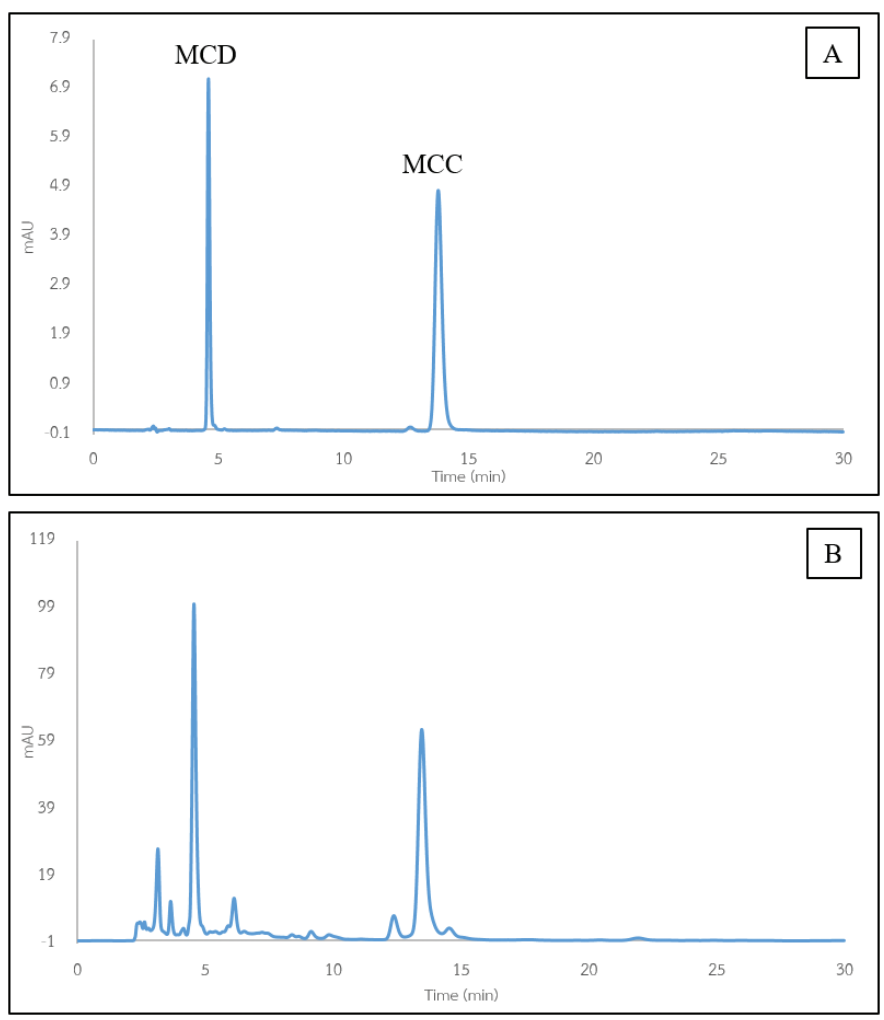

Figure 1. HPLC chromatograms. (A) MCD and MCC. (B) Ethanol-extracted $\mathrm{MCD}$ and $\mathrm{MCC}$ from EPE.
Precision was studied by measuring the intraday (repeatability) and interday or intermediate precision. The precision was expressed by the percentage relative to the standard deviation. The percentage RSD of repeatability and intermediate precision were $1.03-\% 5.80 \%$ and $3.14 \%-6.84 \%$, respectively (Table 2), at an acceptable level according to the AOAC (2016) manual.

The accuracy of the proposed method was tested by adding a standard solution at three concentrations to the $E$. pavieana crude extract. The recovery of MCD and MCC was between $91.94 \%$ and $100.44 \%$ and $99.08 \%$ and $102.75 \%$, respectively, at an acceptable level according to the AOAC (2016) manual.

\section{Extraction optimization of MCC and MCD from E. pavieana rhizome}

Several studies suggest that the solubility of phenolic compounds is dependent on the polarity of the solvent used in the extraction (Boeing et al., 2014; Iloki-Assanga et al., 2015; Lopes et al., 2018). Therefore, we determined the effect of different solvents and extraction methods on the content of MCD and MCC in the E. pavieana rhizome extracts. The contents of MCD and MCC in the extract calculated from the calibration curve produced the relationship between the concentration of analyte and the peak area obtained from the validated HPLC technique. The results revealed that ethyl acetate extraction yielded the largest amount of MCD and MCC, followed by ethanol, 70\% ethanol, and 40\% ethanol, respectively (Fig. 2). A similar trend was observed for the MCD and MCC contents in the extracts by the maceration and reflux extraction methods. There was no significant difference $(p>0.05)$ in the contents of MCD and MCC in the extracts by the maceration and reflux

Table 1. The performance characteristics of the proposed HPLC method.

\begin{tabular}{lcc}
\hline \multirow{2}{*}{ Characteristics } & \multicolumn{2}{c}{ Analyte } \\
\cline { 2 - 3 } & $y=48.835 x-11.983$ & $y=40.607 x-26.737$ \\
\hline Regression equation & 0.9993 & 0.9993 \\
Correlation coefficient $\left(r^{2}\right)$ & $0.25-200.00$ & $2.50-200.00$ \\
Linearity Range $(\mu \mathrm{g} / \mathrm{ml})$ & $1.00-20.00$ & $2.50-60.00$ \\
Calibration curve $(\mu \mathrm{g} / \mathrm{ml})$ & 12.48 & 31.26 \\
LOQ $(\mathrm{ng} / \mathrm{ml})$ & 4.16 & 10.42 \\
LOD $(\mathrm{ng} / \mathrm{ml})$ & $91.94-100.44$ & $99.08-102.75$ \\
Recovery $(\%)$ & & \\
\hline
\end{tabular}

Table 2. The repeatability and intermediate precision of the proposed HPLC method.

\begin{tabular}{cccc}
\hline Analyte & $\begin{array}{c}\text { Concentration } \\
(\boldsymbol{\mu g} / \mathbf{m l})\end{array}$ & $\begin{array}{c}\text { Repeatability } \\
(\% \mathbf{R S D}, \boldsymbol{n}=\mathbf{1 0})\end{array}$ & $\begin{array}{c}\text { Intermediate precision } \\
(\% \mathbf{\% S D}, \boldsymbol{n}=\mathbf{9} \text { days })\end{array}$ \\
\hline MCD & 2.0 & 5.80 & 6.84 \\
& 10.0 & 1.80 & 6.05 \\
& 20.0 & 1.79 & 4.43 \\
MCC & 2.5 & 3.46 & 3.14 \\
& 10.0 & 3.41 & 6.07 \\
& 40.0 & 1.03 & 3.70 \\
\hline
\end{tabular}



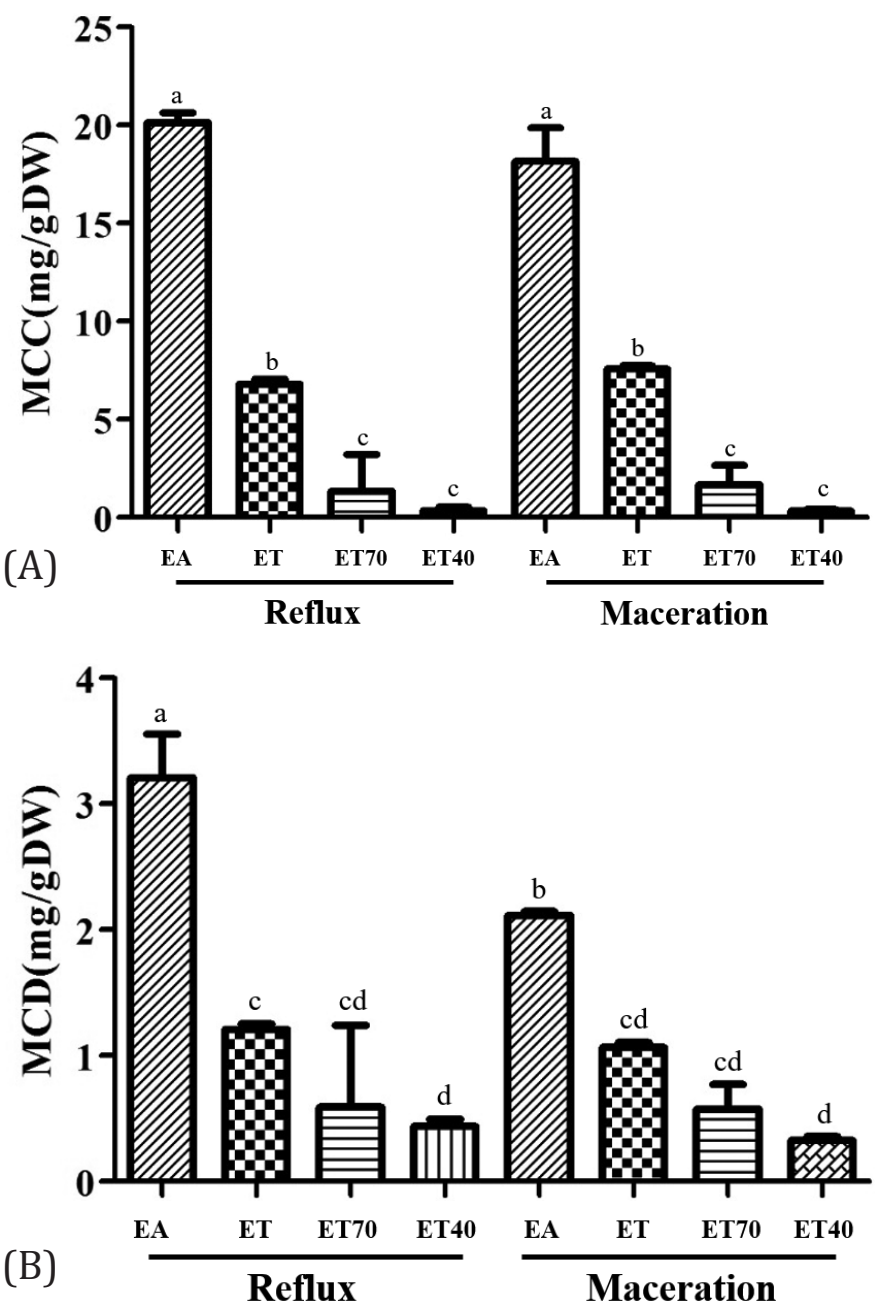

Figure 2. Contents of MCD (A) and MCC (B) of E. pavieana rhizome extracts using different solvents and different methods, maceration or reflux. Values with different letters are significantly different $(p<0.05)$. EA, EPE extracted by ethyl acetate. ET, extraction by ethanol. ET70, extraction by $70 \%$ ethanol. ET40, extraction by $40 \%$ ethanol.

methods using the same solvent except ethyl acetate. A higher MCD content was found in the ethyl acetate extract by the reflux method than the maceration method. Since a phenol group of MCD or MCC is protected by a methyl group in the methoxy group, MCD and MCC are less polar than their corresponding phenolic compounds. Therefore, ethyl acetate, which is less polar than ethanol or aqueous ethanol, is the best solvent for extracting MCC and MCD from EPE. The data from the present study indicated that the polarity of a solvent affected the extraction of both MCD and MCC, and the extraction method affected the yield of MCD.

\section{CONCLUSION}

The HPLC method for the simultaneous determination of MCD and MCC in E. pavieana was validated. The proposed method was demonstrated to be sensitive, precise, and accurate. It can be used for quantifying MCD and MCC in EPE, a potentially significant source of active ingredients for natural health products.
This method would be beneficial for the quality control of raw materials and extracts of E. pavieana.

\section{ACKNOWLEDGMENTS}

This work was financially supported by the Research Grant of Burapha University through the National Research Council of Thailand (Grant no. 13.1/2562) and the Research Unit of Natural Bioactive Compounds for Healthcare Products Development. The authors would like to thank the Center of Excellence for Innovation in Chemistry (PERCH-CIC), Ministry of Higher Education, Science, Research and Innovation, and thank Ms. Kulisra Pothipathom and Ms. Waratchaya Yaemem for valuable technical assistance.

\section{AUTHOR CONTRIBUTIONS}

All authors made substantial contributions to conception and design, acquisition of data, or analysis and interpretation of data; took part in drafting the article or revising it critically for important intellectual content; agreed to submit to the current journal; gave final approval of the version to be published; and agree to be accountable for all aspects of the work. All the authors are eligible to be an author as per the international committee of medical journal editors (ICMJE) requirements/guidelines.

\section{CONFLICT OF INTEREST}

The authors declare no conflict of interest.

\section{ETHICAL APPROVALS}

This study does not involve experiments on animals or human subjects.

\section{PUBLISHER'S NOTE}

This journal remains neutral with regard to jurisdictional claims in published institutional affiliation.

\section{REFERENCES}

AOAC. Official methods of analysis. 20th edition, AOAC International: Association of Official Analytical Chemists, Gaithersburg, MD, 2016.

Boeing JS, Barizão EO, E Silva BC, Montanher PF, de Cinque Almeida V, Visentainer JV. Evaluation of solvent effect on the extraction of phenolic compounds and antioxidant capacities from the berries: application of principal component analysis. Chem Cent J, 2014; 8:48.

Iawsipo P, Srisook E, Ponglikitmongkol M, Tatiyar S, Singaed O. Cytotoxic effects of Etlingera pavieana rhizome on various cancer cells and identification of a potential anti-tumor component. J Food Biochem, 2018; 42:e12540.

ICH. Validation of analytical procedures: text and methodology Q2(R1). In: IFPMA (ed.). International Conference on Harmonization of Technical Requirements for Registration of Pharmaceuticals for Human Use. IFPMA, Geneva, Switzerland, 2005, pp 1-13.

Iloki-Assanga SB, Lewis-Luján LM, Lara-Espinoza CL, GilSalido AA, Fernandez-Angulo D, Rubio-Pino JL, Haines DD. Solvent effects on phytochemical constituent profiles and antioxidant activities, using four different extraction formulations for analysis of Bucida buceras L. and Phoradendron californicum. BMC Res Notes, 2015; 8:396.

Lopes AP, Petenuci ME, Galuch MB, Schneider VVA, Canesin EA, Visentainer JV. Evaluation of effect of different solvent mixtures on the phenolic compound extraction and antioxidant capacity of bitter melon (Momordica charantia). Chem Pap, 2018; 72:2945-53. 
Mankhong S, Iawsipo $\mathrm{P}$, Srisook $\mathrm{E}$, Srisook K. 4-methoxycinnamyl p-coumarate isolated from Etlingera pavieana rhizomes inhibits inflammatory response via suppression of NF- B, Akt and AP-1 signaling in LPS-stimulated RAW 264.7 macrophages. Phytomedicine, 2019; 54:89-97.

Naksang P, Tongchitpakdee S, Thumanu K, Oruna-Concha MJ, Niranjan K, Rachtanapun C. Assessment of antimicrobial activity, mode of action and volatile compounds of Etlingera pavieana essential oil. Molecules, 2020; 25:3245.

Poulsen DA, Phonsena P. Morphological variation and distribution of the useful ginger Etlingera pavieana (Zingiberaceae). Nord J Bot, 2017; 35:467-75.

Srisook E, Palachot M, Mankhong S, Srisook K. Antiinflammatory effect of Etlingera pavieana (Pierre ex Gagnep.) R.M.Sm. rhizomal extract and its phenolic compounds in lipopolysaccharidestimulated macrophages. Pharmacogn Mag, 2017; 13:S230-5.

Srisook K, Mankhong S, Chiranthanut N, Kongsamak K, Kitwiwat N, Tongjurai P, Aramsangtienchai P. Anti-inflammatory effect of trans-4-methoxycinnamaldehyde from Etlingera pavieana in LPSstimulated macrophages mediated through inactivation of NF- $\mathrm{kB}$ and JNK/ c-Jun signaling pathways and in rat models of acute inflammation. Toxicol Appl Pharmacol, 2019; 371:3-11.
Srisook K, Potiprasart K, Sarapusit S, Park CS, Srisook E. Etlingera pavieana extract attenuates TNF- induced vascular adhesion molecule expression in human endothelial cells through NF-_B and Akt/ JNK pathways. Inflammopharmacology, 2020; 28:1649-62.

Srisook K, Udompong S, Sawai P, Thongyen T. Etlingera pavieana rhizome extract decreases oxidative stress and activates eNOS activity via stimulation of Akt phosphorylation in human endothelial cells. Naresuan Phayao J, 2018; 11:23-8.

Tachai S, Nuntawong N. Uncommon secondary metabolites from Etlingera pavieana rhizomes. Nat Prod Res, 2016; 30:2215-9.

\section{How to cite this article:}

Srisook K, Malapong C, Sawai P, Srisook E. Validation of quantitative RP-HPLC-DAD method and extraction optimization of 4-methoxycinnamyl $p$-coumarate and trans4-methoxycinnamaldehyde in Etlingera pavieana rhizomes. J Appl Pharm Sci, 2021; 11(10):029-034. 


\section{SUPPLEMENTARY FIGURE}

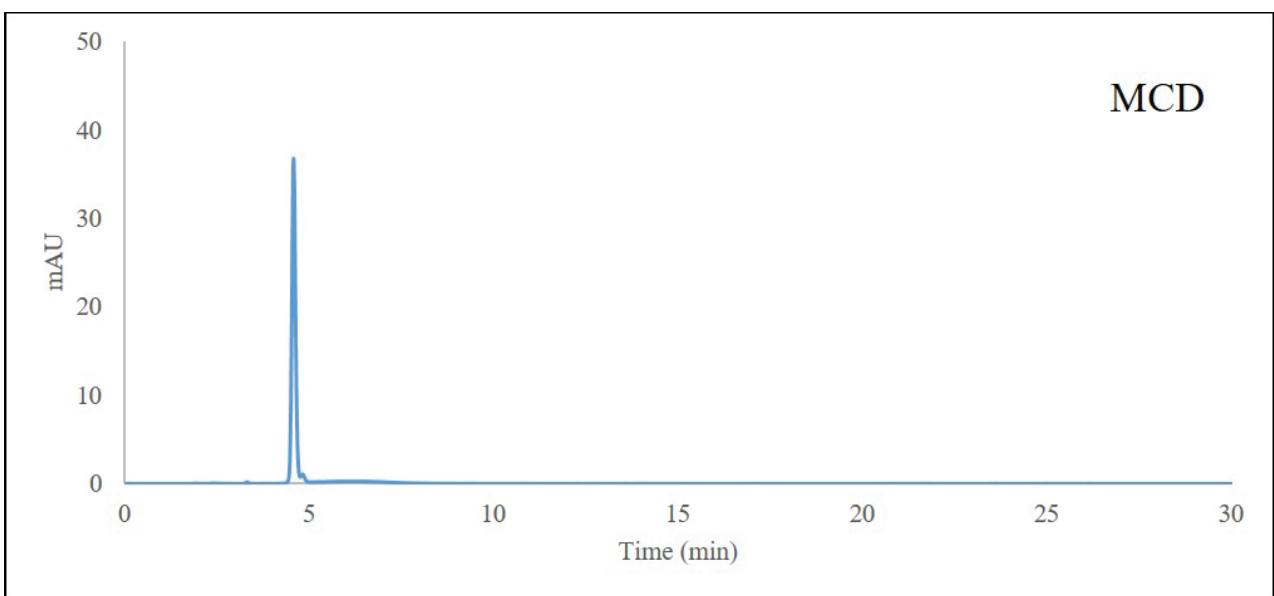

Figure S1. High performance liquid chromatography chromatogram of trans-4-methoxycinnamaldehyde (MCD) detected at $320 \mathrm{~nm}$.

(A)

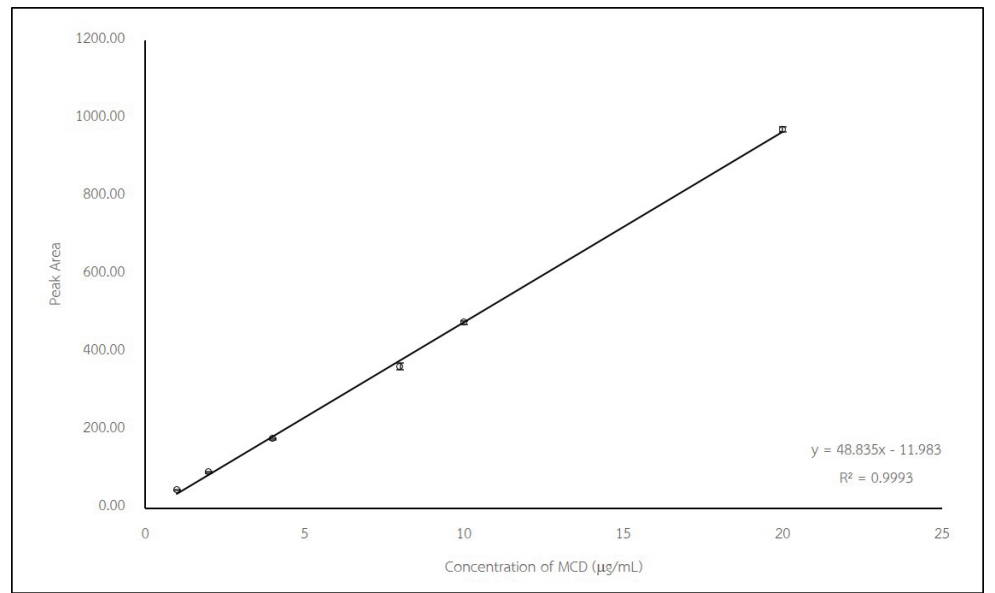

(B)

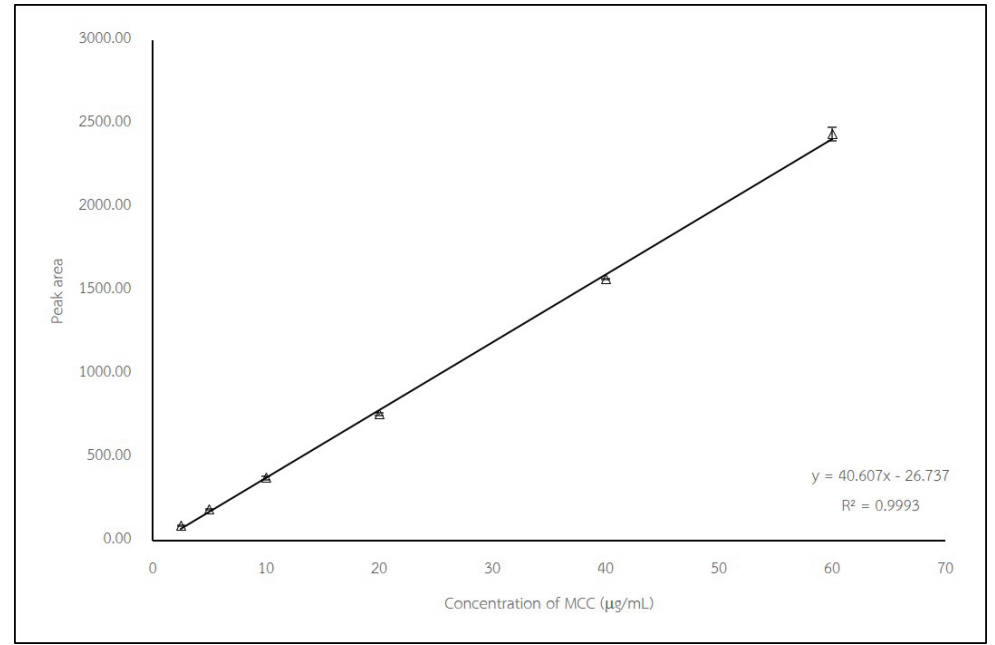

Figure S2. Calibration Curve of MCD (A) and MCC (B). 